\title{
Fostering Elite Athlete Development and Recreational Sport Participation: a Successful Club Environment
}

\author{
Larissa Rafaela Galatti ${ }^{*}$, Jean Côté ${ }^{2}$, Riller Silva Reverdito ${ }^{3}$, Veronica Allan², Antonio \\ Montero Seoane ${ }^{4}$, Roberto Rodrigues Paes ${ }^{5}$
}

ORIGINAL ARTICLE

\begin{abstract}
The overall aim of this article was to present a positive case study about how a sport club can foster both elite athlete development in parallel with offering a diverse range of sport activities to attract and maintain a greater number of children and youth for continued participation in a long term sport program. To this end, an in-depth case study was conducted of a model Spanish Basketball Club, considered an example of success in achieving consistent level of performance and high rates of participation among their youth. Data were collected from in-depth interviews with administrators, setting observation, and analysis of current and archived club documents. The results show that the club has created changes over the years that have led to a clear organizational structure with a philosophy that connects its youth development teams and elite teams. An increase focus on youth development, the addition of recreational activities, and the implementation of a coach education program have been linked to enhanced participation rate and performance.
\end{abstract}

Keywords: Athlete Development, Sport Participation, Youth Sport, Sport Club

\section{INTRODUCTION}

Sport is one of mankind's greatest sociocultural phenomena. Nowadays, sports clubs are one of the main organizations supporting sports in various countries around the world - they are the key institution of elite sports in Latin America and Europe, while playing a similar role in several other countries (Galatti, 2010; Heinemann, 1999; Jakobsson, 2012; Paes \& Galatti, 2013; Rodríguez Díaz, 2008). Worldwide, clubs are an important context where youths learn and develop themselves in a sport discipline. However, the search for new elite athletes has lead clubs to maintain a pyramidal model of talent selection, early specialization, and constraint, which holds several implications for developing youth and the institution itself (Galatti, Reverdito, Scaglia, Paes, \& Seoane, 2014; Heinemann, 1999; Rodríguez Díaz, 2008).
The search for new elite athletes is not the issue; the issue is that this search appears to be misguided and restricted to only some aspects of athletes' so-called talent, particularly considering the restriction of several sport programs to a pyramidal model that excludes "less talented" children and teenagers from the process (Côté, Lidor, \& Hackfort, 2009; Fraser-Thomas, Côté, \& MacDonald, 2010; Galatti, 2010; Henriksen, Stambulova, \& Roessler, 2010; Jakobsson, 2012; MacDonald, Côté, Eys, \& Deakin, 2011; Strachan, Côté, \& Deakin, 2011).

According to Côté, Lidor, and Hackfort (2009), the current trends in sport programming are institutionalization, elitism, early selection and specialization. What traditional sport programs for youth in clubs do not use to consider is that the development of skills that lead to excellence in sport occurs from the

Manuscript received at November $13^{\text {th }} 2014$; Accepted at September $8^{\text {th }} 2016$

${ }^{1}$ School of Applied Sciences, University of Campinas, Limeira, Brazil

${ }^{2}$ Queen's University, Kingston, Canada

${ }^{3}$ Faculty of Health Sciences, State University of Mato Grosso, Cáceres, Brazil

${ }^{4}$ University of Coruña, La Coruña, Spain

${ }^{5}$ Faculty of Physical Education, University of Campinas, Campinas, Brazil.

* Corresponding author: Faculdade de Ciências Aplicadas da Unicamp - R. Pedro Zaccaria, 1300 . Caixa Postal 1068, CEP 13484-350 - Limeira - São Paulo. E-mail: lagalatti@hotmail.com 
successful interaction of biological, psychological, and sociological factors; the interaction of these factors occurs in relation to two key aspects: the training process and the environment, considering them not as separate components, but elements of the same organically designed system (Baker, 2003; Ferreira \& Moraes, 2012; Galatti et al., 2014; Henriksen et al., 2010; Holt \& Dunn, 2004; Morgan \& Giacobbi, 2006; Phillips, Davids, Renshaw, \& Portus, 2010; Viola, Paes, Galatti, \& Ribeiro, 2011).

Baker (2003) suggested that combining quantity and quality of training and environment with suitable coaches and family support are essential elements for the development of elite level athletes. The roles of coaches and other coaching staff, teammates, elite athletes (i.e., role models) and peers are a fundamental component of this process, in addition to family, friends and others beyond the sporting environment that offer social support to athletes in a trajectory where success is expected (Baker, 2003; Holt \& Dunn, 2004; Morgan \& Giacobbi, 2006).

Alongside the importance of interpersonal relationships, the training activities provided to young athletes in the sport club environment are also an important determinant of their future success. Côté and colleagues have presented a developmental model of sport participation (DMSP) that outlines the possible trajectories an individual may follow from initiation in sport through to adulthood (Baker, Côté, \& Abernethy, 2003; Côté, Baker, \& Abernethy, 2007; Côté \& Fraser-Thomas, 2007; Fraser-Thomas, Côté, \& Deakin, 2005, 2008). To the authors, diversifying types of sport activities may keep children longer in sport environment, and can contribute for a lifetime in sport participation, and can increase the possibility of revealing an elite athlete

The social contexts created by diversifying the learning environments are qualitatively different, as are the resultant learning and motivational outcomes (Côté, Erickson, \& Abernethy, 2013). However, traditional sport programs, particularly in the club context, tend to structure their programs on deliberate practice activities and organized competitions (Côté et al., 2009; Côté, Strachan, \& Fraser-Thomas, 2008). In the last few years, there has been an increase in play practice in some of these programs (Davids, Araújo, Correia, \& Vilar, 2013; Fradua et al., 2013; Hill-Haas, Dawson, Impellizzeri, \& Coutts, 2011), but the provision of opportunities for youth-led activities such as deliberate play and spontaneous practice remains of little concern for many clubs.

Finally, the physical setting in which sport takes place is an important element that affects youth involvement in sport. More than 25 years ago, Carlson (1988) used Bronfenbrenner's ecological approach in elite tennis players in Sweden highlighting the importance of the "place of development" as a determinant of participation and talent development in sport. Well after, researchers continued to examine the dynamic of larger sport systems such as successful university sport programs (e.g. Vallée \& Bloom, 2005) and sporting clubs (e.g. Henriksen et al., 2010; Henriksen, Stambulova, \& Roessler, 2011). These studies highlight several features of settings that contribute to athletes' performances and participation including, among others, the importance of proximal role models, training that allows for diversification, and positive coachathletes relationships.

Maintaining the engagement of children and adolescents is of particular relevance to the continued success of sports clubs. Considering the varied and complex factors that contribute to youth engagement in sport (e.g., activities, relationships, and settings), the question persists: How can sport clubs promote sport programs that focus on the development of elite athletes while also facilitating long-term participation and positive youth development in sport? Thus, the purpose of this study was to present a positive case study about how a sport club can foster both elite athlete development in parallel with offering a diverse range of sport activities to attract and maintain a greater number of children and youth for continued participation in a long term sport program. The case study was conducted in a model Spanish basketball sport club, considered the best youth sport club in Galicia state in the studied season (Sport and Cultural State Council), and a national example of success and excellence in youth academy sport management (El País Newspaper). 


\section{METHODS}

This qualitative in-depth case study was conducted in two phases: (1) the exploratory phase, and (2) the active phase. First, the exploratory phase included a preliminary research design; it also incorporated documental research, a review of archival documents to describe the history of the club and the club sport program. Next, the active phase involved delimiting the problem, collecting data, and analyzing and interpreting results from interviews and participant observation (via field diary) with one of the researchers at work as a coach in the club's activities (Anguera-Argilaga, 1999). These two phases will be described separately, with the corresponding results.

\section{Phase 1: Phase 1 - Environment: Knowing the Setting and Justifying the Choice of the Case}

The study was carried out in a basketball club in the north of Spain, in the region of Galicia, during a complete season (fictional name “ $C L U B^{\prime}$ "). In addition to articles obtained from national, regional, and local magazines and newspapers, documents of the Galician Federation of Basketball and internal club documents, including meeting minutes and legal documents, were consulted as a part of the document review process. As a result of this document research, the following inquiry was addressed: "What is the recent trajectory of this club that reflects its success in the elite team and youth participation sport, both in sporting results (elite) and the number of participants (youth)?"

\section{Phase 2 - Interviews and Observation: sample, instrument, proceedings and analyses}

Grounded in the findings of phase 1, the objective moving into phase 2 was to answer the following inquiry: "Which intentional actions by $C L U B$ favored its constant growth in both the participation of children and youth and elite sport performance?"

Individuals directly involved with the basketball program in CLUB during the 20082009 season were participants or observed in the study, namely: the presidency and directors, one elite team in a national professional league organized by the Spanish Basketball Federation (FEB-LEB Bronce), 432 athletes enrolled in all youth development teams at the ages mandated by the Galicia Basketball Federation (FGB), approximately 120 children in the development basketball classes in local schools, and 32 coaches.

Knowing how a club works means listening to its members, since the club is not only a bureaucratically structured organization, but also a reflection of its members' values (Heinemann, 1999). In order to respect the specificities of the club, the methodology adopted was participant observation, with the researcher taking up the role of an Under-12 Youth Team's coach during the season investigated. Field diaries and semistructured interviews were used. The field diary recorded information about the club's routine, with attention to the actions employed in implementing the sports program in training practices, the pedagogic meetings between coaches and coordinators, the official games of both the youth development teams and the adult professional team, and any other activities developed by the club (e.g., sports camps). This observation gave the principal researcher a profound feel for the culture (Henriksen et al., 2010).

The interviews were carried out with 12 managers of the club: eight from previous administrations (including all presidents, vicepresidents, and sports managers) and four from the administration in charge during the season investigated, excluding one municipal sports manager. The interviews were scheduled individually and performed at the preferred place and time of each collaborator. Moreover, the order of the interviews followed the chronology of the interviewees' involvement with the club. The goal was to identify and describe the club and the operation of its sport program, as well as the commercial and social actions and services currently offered. A Sony ICD-P520 digital audio recorder was used to record the interviews, which were conducted in Spanish and transcribed in that language immediately following each interview.

All the interviews conducted with the past managers help to establish a time line of events 
that set the stage for the interview with the current managers of the CLUB. Although we interviewed all the managers in the history of the club, we conducted an in-depth analysis of the three managers in action in the studied season. Each interview was transcribed and organized into categories of information relevant to the research question; the categories were determined after the data had been collected (Bardin, 2011). The study followed the research ethics procedures in effect in Spain and all participants signed the Term of Free Informed Consent in the local language.

\section{RESULTS}

\section{Phase 1}

From the documental research, it is described that the CLUB was founded in 1996 and between 2001 and 2004 it lived a financial and administrative crises that almost caused it to close down. Over this period, $C L U B$ focused on the elite team, in what Rodríguez Díaz (2008) calls "intensive" offer, in which few athletes of high technical level are privileged so as to achieve significant results in competitions with the highest possible level of demand. In those cases, it is quite common to see an adult elite team with the minimum number of youth development teams, relying on a large external sponsor, which causes great dependency and instability in maintaining sports programs (Galatti, 2010).

In 2004, following changes in its administrative staff, CLUB decided to maintain the elite team and seek the best possible sports results, but with one additional objective: a sport program based on the expansion of youth development teams. By investing in the formation of a social group linked to the club, a greater number of children and youth were able to participate in the club and a larger consumer base enabled the diversification of actions promoted by the club. Since the changes made in the 2004-2005 season, the organizational structure and action strategies of the club are described in the $C L U B$ 's Sport Program ${ }^{1}$. From this date until the season investigated, 2008-
2009, CLUB saw an increase of $374.5 \%$ in the number of athletes, as demonstrated in Figure 1. Following this continuous growth in the number of $C L U B$ athletes, the competitive level of $C L U B$ has also continued to increase with each progressing season: $C L U B$ 's elite team has continuously joined higher performing leagues since the 2004-2005 (progressing through 4 divisions, one each year, coming to "LEB Plata" division).

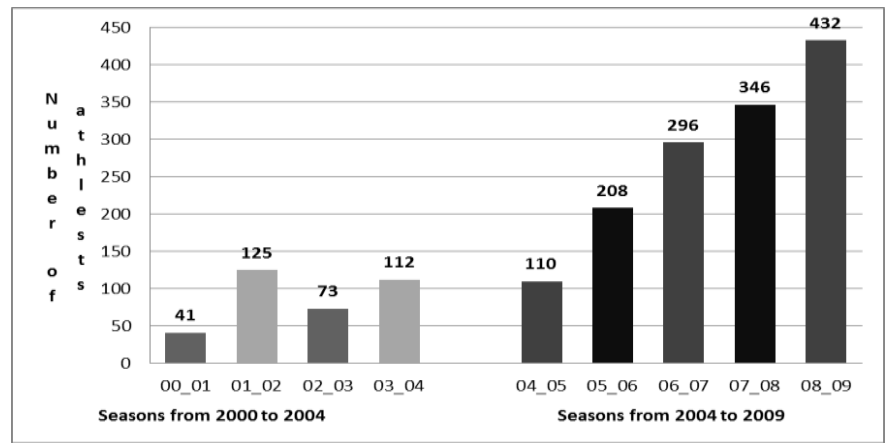

Figure 1. Number of athletes federated by CLUB between 2000 and 2009 (source: Federación Galega de Baloncesto).

As the results show, increasing the participation of youth in CLUB appears to have positively affected the performance of its professional team. After $C L U B$ 's sport program was showcased in the main nationwide newspaper in Spain, El País, the CLUB was nationally recognized and subsequently elected as the best club for the promotion of youth sports (in all the state and among all sports) in 2010 by the Council of Culture and Sports of the Autonomous Region of Galicia.

\section{Phase 2}

Nine categories were identified from the interviews 'data: (1) organizational structure, (2) club philosophy, (3) sport program, (4) youth development teams, (5) recreational activities, (6) elite team, (7) relationship between youth teams and first team, (8) coach education, (9) club image and social impact.

(1) Organizational structure: CLUB is classified as an elite sport club, whose actions are 
centered towards their representative teams (Rodríguez Díaz, 2008). This type of club has a sustained structure of an administrative board and staff, relying on a small number of members and a larger number of supporters.

The governing board consisted of 12 volunteers and many of them had children who were playing in CLUB and professions that enabled the skills and tools valuable for the running of the club (e.g., business, banking, advertising, etc.). In general, the governing board contributed to the prestige or professional nature of $C L U B$ s personal and social life (Heinemann, 1999). The staff, all paid, was composed of a sport manager, four full-time coaches, and 28 part-time coaches. The coaches are responsible for all lessons and training, the coordination of competition within the organization, and the implementation of activities sponsored by the club.

The amateur board of directors has clearly differentiated roles from those of the sport manager and coaches. The volunteer board is responsible for the financial organization of the club, in addition to the preparation of $C L U B$ s $\mathrm{s}$ sport program. In line with the common philosophy outlined in $C L U B$ s sport program, the sport manager and coaches, all of whom are paid staff, apply the sports program, coordinate and direct all teams, and perform $C L U B^{\prime} \mathrm{s}$ activities. The sports manager is responsible for the link between amateur directors and paid staff; although there are differences in priorities, these groups seek understanding from common goals and compliance with the athletic program.

(2) Club philosophy: CLUB's mission is to provide access to a quality basketball program and increase the number of participants associated with $C L U B$ through the provision of two key features: (a) the potential for performance at the elite sport level, and (b) an educational program of mass sport. This philosophy was evident in the views of the managers, as well as in the documents of the club.

(3) Sport Program: The structure of the sport programming in CLUB encompassed three sectors: (a) an elite team, (b) youth development teams, and (c) recreational activities. Each of these sectors can be defined on an interrelated level; the youth teams feed the elite team, both as athletes and a supporting social mass, and recreational activities serve to attract new members to the club, youth participants and spectators alike.

(4) Youth Development Teams: CLUB serves more than 500 children and adolescents from 6 to 18 years of age, including 432 youth athletes registered with the Galician Basketball Federation and approximately 120 children in beginner basketball classes offered at municipal facilities and private schools.

The significant number of athletes participating on youth teams is attributed, among other factors, to a paradigm shift in the club: the extinction of selective choice among youth athletes, and expansion to include a base of multiple teams that has allowed the club to form public support and spectator basketball. To this end, the club has allocated the best trained coaches (graduates in Physical Education) to the divisions of initiation and first categories, promoting classes and quality care.

Children and parents who come to the club often do not aspire, initially, to become elite athletes; thus, $C L U B$ approaches new athletes with the goal of providing an environment for education and human development through sport participation. This does not preclude the pursuit of sporting results and quality technical and tactical instruction on each recreational team, however, there is no exacerbated pressure to win. In addition to promoting participation among children and adolescents, the families of these athletes begin to follow the everyday occurrences of the club, watching training and competition activities for both children and the elite team, and increasing the social mass of $C L U B$ as a result.

(5) Recreational Activities: This category referred to sporting and social activities offered to $C L U B$ 's domestic audience that are related to basketball but go beyond the extent of regular competitions. These activities include events such as sport camps, recreational tournaments, basketball meetings, athlete clinics, coach clinics, sport tourism, jamboree and others. Each of these activities is intended to provide young CLUB basketball players with new ways to experience basketball. 
These activities are targeted to the wider community as well, promoting the CLUB and attracting new members for youth teams just as spectators are drawn to the elite team. Additionally, such activities provide economic support for the club by attracting private sponsorship and funding from public programs related to health and physical education. Thus, recreational activities and youth development programs are complementary strategies that promote $C L U B$ s image, illustrating a trend of diversified services which, when well offered, recruit new users to the club.

(6) Elite team: it is the showcase of the club, performing at the national and professional level. The team maintains a strong representation and identity in the local community, with several players born in the surrounding city/state. While a source of major expenditures for the club, the elite team is also an important source for fundraising via marketing strategies and advertising. Furthermore, the elite team serves as the stimulator for more than 500 children and youth who practice basketball at the club, in addition to over 2000 people who crowd the municipal gym on a weekly basis, raising the local social value.

(7) Relationship between youth teams and elite team: There is a relationship of mutual collaboration; the youth development teams psychologically motivate the elite team which, in turn, feeds the desires of children and young people in the sport of basketball, perhaps inspiring future elite athletes and offering a means for expansion of the sporting culture related to basketball citywide. The political aspect of this relationship is also highlighted, given that the large number of entries with the FGB strengthens $C L U B$ at these institutions, generating economic empowerment as a large number of people are willing to consume the products related to this sport. Thus, in the case of the $C L U B$, there is an aspect of interdependence between recreational and professional sport.

(8) Coach Education: The hiring of strong technical staff in the sport of basketball was considered crucial to the success of this program. Several coaching education and follow-up strategies were employed, of which stand out: (a)
$C L U B$ 's coaching meetings; (b) publicizing and demanding social-educational programs to be carried out with the youth development teams; (c) filling out the Coach's Notebook (the club's own model); (d) promoting internal courses to inform coaches and supporting coaches' participation in courses promoted by the FGB and FEB; (e) a mentoring program in which new coaches in the institution are followed by a more experienced coach with a background in the club; and (f) financially valuing the achievement of the club's propositions with a monthly bonus of up to $20 \%$ of the coach's salary. In addition to these tactics, the parents of young athletes answer questionnaires to follow and assess the work of the coaches. As a result of the guidance from $C L U B$ coordinators and the training offered by the club, the coaches learn the demands of the job and how to perform most effectively.

(9) Club image and Social Impact: CLUB has achieved social recognition in both its internal community (i.e., children and youth, athletes, parents, fans) as well as in the broader external community (i.e., press, associations, citizens). The social standing that has been achieved by $C L U B$ is largely attributed to the quality care of a large number of children and young people, constant intervention with the community through recreational activities, and the development of local professional players, creating a team identity that resonates within the city.

\section{DISCUSSION}

By analyzing $C L U B$ 's sport program, the objectives $C L U B$ seeks to achieve are clear: (a) the promotion of basketball in the greater city community, (b) strengthening its elite team through an elite model, while also (c) expanding the youth development teams to go beyond only forming athletes, with the inclusion of educational concerns regarding the overall development of children and youth participating in the club.

In this structure, the youth development teams - 432 players that make up 30 different teams - are the ones involving the largest number of sports coaches working in the club. The large number of athletes participating in the youth 
academies is attributed, among other factors, to a shift in the club's paradigm: The end of trials for choosing athletes admitted to a few select teams, and the investment in multiple youth development teams that allow the club to form a public following that both practices and watches basketball. Therefore, the club's sports program favors a diverse practice that enables children and young people to learn a sport, and thereafter remain in the sport with the option to either specialize in the club and aspire to be an elite athlete, or continue to play on competitive teams and participate in recreational activities with the goal of lifelong sport participation (Côté et al., 2009; Fraser-Thomas et al., 2005, 2008; Paes \& Galatti, 2013; Strachan et al., 2011).

This process begins with the recreational activities, directly linked with the youth development teams, as a way of publicizing the club by offering quality services and professionals. From this first contact with the $C L U B$, children and youngsters gain an interest in basketball and many enroll in the youth development teams. In this way, recreational activities and youth teams complement one another and are strategic for the club's image, illustrating a trend in diversifying services, which, when offered properly, attract new users to the club (Heinemann, 1999). These activities provide children with the opportunity to act autonomously in engaging with the sport, because they have free time to explore the basketball court (Côté et al., 2013; Viola et al., 2011).

Furthermore, parents and friends that do not play in $C L U B$ s youth basketball academy can participate in these activities, which can create a stimulating environment where young athletes feel supported by relatives and friends (Baker, 2003; Ferreira \& Moraes, 2012; Galatti et al., 2014; Holt \& Dunn, 2004; Morgan \& Giacobbi, 2006). Achieving this level of extensive social support and family involvement has the potential to keep young basketball players in the club throughout childhood and adolescence, potentially serving as future elite players (Baker, Deakin, \& Cote, 2005; Côté et al., 2009; FraserThomas et al., 2010; Galatti, 2010; Henriksen et al., 2010, 2011; MacDonald et al., 2011; Strachan et al., 2011), and increasing the possibility of lifelong sport participation (Côté et al., 2013; Silva, Galatti, \& Paes, 2010). Thus, offering youth academies must go beyond the formation of professional athletes; it must promote human development in children and teenagers who seek the sport through an institutionalized extracurricular educational process (Côté et al., 2009; Fraser-Thomas et al., 2008; Paes \& Galatti, 2013; Strachan et al., 2011).

Although sporting results and technicaltactical quality are sought in each of the youth development teams, there is no overwhelming pressure for the teams to perform successfully since the club aims to develop not only the athlete, but the person as well, by providing an educational service. On the other hand, offering young individuals the opportunity to sample several different sports without any emphasis on specialization and technical-tactical development can be useful in promoting elite athletes as well (Abbott \& Collins, 2004; Bailey \& Morley, 2006; Baker et al., 2003; Balyi, 2002; Côté et al., 2013; Leite, Baker, \& Sampaio, 2009). In order for this to occur, a coach education program was developed within the CLUB.

$C L U B$ 's sports program goes beyond the success of the elite team and developing new elite athletes, demonstrating a focus on internal communication and educational requirements that foster well-rounded youth development teams. The coaches are encouraged to talk to the parents, be attentive, and fulfill the basketball system, an educational program by the club that aims to reinforce a set of values pertaining to healthy habits, positive attitudes, attendance, interaction with the team, punctuality, respect, and good grades. An approach that focuses on values helps to increase parents' confidence in the club and keeps them close to the activities undertaken, which is critical to children's development in sport (Baker, 2003; Ericsson, Krampe, \& Tesch-Romes, 1993; Ferreira \& Moraes, 2012). It is an action that shows the club's pedagogic concern in terms of sports initiation and human formation (Côté et al., 2009; Fraser-Thomas et al., 2008; Heinemann, 1999; Jakobsson, 2012; Strachan et al., 2011). From an administrative perspective, the club 
president highlights the basketball system in demonstrating the educational focus of the sports program that must be fulfilled by the president, directors, managers, and coaches.

Hence, the club's goal of developing an elite sport program in conjunction with a broad base of child and youth participants has allowed for $C L U B$ to offer quality sport programming in association with an educational program. Increasing the number of CLUB members has also led to its third cornerstone: Recreational activities for the purpose of participation. In the developmental model of sport participation (DMSP), the authors indicate that sport initiation moving away from early specialization and engaging fully in the sampling years (characterized by relatively high levels of deliberate play and low levels of deliberate practice in a variety of sports) favors the optimal trajectory for both elite performance and lifelong sport participation (Côté et al., 2007; Côté \& Fraser-Thomas, 2007; Fraser-Thomas et al., 2005, 2008).
The structure of $C L U B$ can be viewed in light of the DMSP, offering recreational activities, multiple youth development teams, and one elite team, which are linked not hierarchically, but rather, are complementary and interdependent. Each of these features cumulate in the stability and continued success of $C L U B$; through each of these venues the club is able to provide a myriad of actions and services to different target groups, enabling federated basketball with a professional team and several youth teams, while also promoting the sport with various possible meanings and experiences.

It is not enough that a club seeking to take part in a professional modality promotes only the elite team. Adding to this point, it is important to develop a mass of people who practice, watch, and follow this team, who get involved with the sport and justify the revenue from investors, while allowing the club to multiply its own actions at the elite, competitive and recreational levels, as shown in figure 2 .

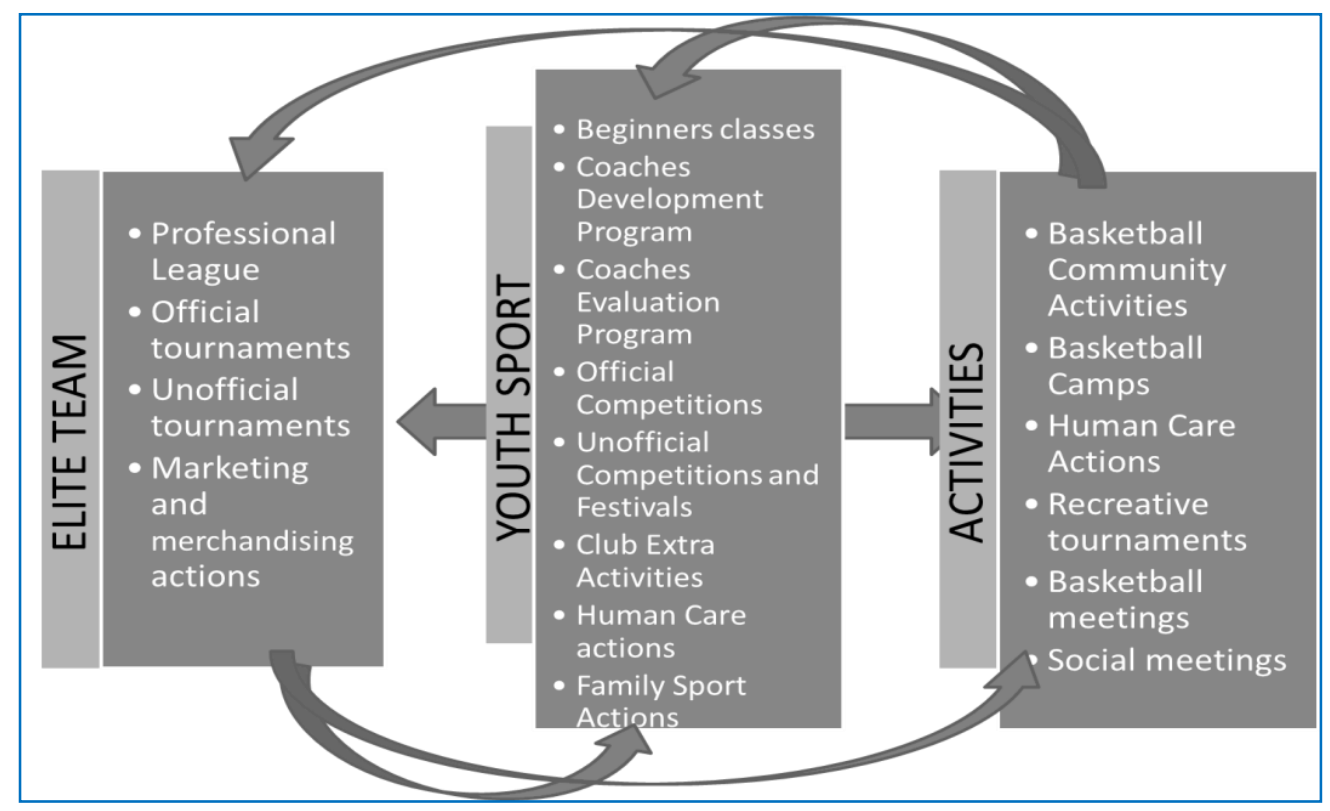

Figure 2. Integrated actions related to CLUB's sports program.

It is important to consider that this investigation is a case report, in which the aims are deep understanding of either a situation or a background in a specific period of time, in this case a sports club with a successful sports program based on the relationship between both elite and youth sports. The observation of the successful factors of this sports club offer in their correlated dimensions was possible due to the methodology applied in the research. However, the results of an investigation of this nature are associated with the conditions evaluated in this specific environment, and require attention to 
the comparisons of the evidences found within other contexts.

Considering this caveat, the results found in this investigation could be better compared with similar studies developed in other sports contexts, which articulate youth and elite sports. However, this will only be possible when the successful experiences of sports offered in the contemporary context come to be studied more often among the sport pedagogy research. Complex and deep studies that aim to understand a wide context of sports development demand time and multiple research techniques. The comprehension of the scientific community about this factor is also important, in which time and effort should not be a deterrent for conducting this type of study.

\section{Conclusions}

Sport in today's society is a contemporary and diversified phenomenon in constant transformation and valued at different social levels. It has multiple social meanings, such as those related to profession, representation, leisure, health, aesthetics, socialization, and education. In this new environment, sports clubs have been struggling to adapt. In light of this statement, this paper reported a positive case study about how a sport club can offer both elite athlete development and a diverse range of sport activities to attract and maintain a greater number of children and youth for continued participation in a long-term sport program. Considering the needs and possibilities raised in the literature review, as well as the findings of this field research, three fronts of action are proposed in order to promote a sports program integrating elite (i.e., performance) and recreational (i.e., participation) sport in the context of the sports club:

1. Elite Team: The elite team provides the most visibility to the club, since it brings together the best athletes, competes at the professional level, and has several elements to draw in the public, investors, partners, and consumers. Additionally, the elite team does not necessarily need to play in the country's main competitive category - a team in division $\mathrm{C}$ or an under-21 team may play the role of a club's elite team and amass members and fans to the club.

2. Youth Development Teams: By investing in multiple youth development teams, clubs can push beyond the paradigm of selecting only the best. These children and youngsters make up, from the beginning, the supporters that bolster the sport; they further amass new supporters in their roles as child- and youth-athletes, involving their parents, siblings, and friends. In the long run, the youth teams may foster the development of future elite players, and people linked to the program may keep in contact as informal players, spectators, coaches, referees, managers, and sponsors, among other roles. The youth development teams may also, through partnerships with schools, city halls, and NGOs, expand the reach of the sport and the club to other institutions.

3. Activities: Various projects and events developed by the club and linked to its sports program strengthen the internal supporters and attract new people to the CLUB. In this sense, leisure activities, informal competitions, festivals, performances, meetings, workshops, etc., strengthen the sport community within the club. These activities may be focused on both current club users and the external public, depending on the statutory requirements and philosophical underpinnings of each club.

In attending to the three key areas outlined above, sports clubs may reap significant benefits. Thus, in order to diversify and optimize the strategies in effect for sports clubs, the following points are highlighted: (a) Value the interdependency between the elite team and associated youth development teams; (b) View youth development teams as a social mass supporting the club, not a source of expenses; (c) Develop the person, not just the athlete; Diversify and tailor the actions to the sport(s) and group(s) involved; (d) Respect the social group characteristics that motivate and maintain the club; (e) Professionalize and develop coaches over time; (f) Recognize coaches as the key players connecting the sports program, board of directors, club members, athletes (of all levels), fans, and all other involved individuals. 
In conclusion, the strategies implemented by $C L U B$ are cause for careful consideration of systematizing more concrete possibilities for restructuring the relationship between sport clubs encompassing aspects of both elite and participation and youth development through sport. However, it is also important to note that each club must be studied according to its own operational standards and context, and that these findings may be adapted, but not necessarily generalized, for use in other clubs. Additionally, greater attention surrounding the educational possibilities concurrent with sport participation can also be emphasized, particularly in the context of child and youth development, which is often viewed as a complement to formal education. To this end, a sports program and pedagogical procedures that meet this demand must be established. A program focused on education through sports does not mean disregarding the role of clubs in forming adult and professional athletes, but rather articulating this primary goal in the youth development teams in the context of elite sports with others that rise in the reality of contemporary sports.

\section{Acknowledgments:}

Nothing to declare

\section{Conflict of Interest:}

Nothing to declare

\section{Funding:}

Nothing to declare

\section{REFERENCES}

Abbott, A., \& Collins, D. (2004). Eliminating the dichotomy between theory and practice in talent identification and development: considering the role of psychology. Journal of Sports Sciences, 22(5), 395-408. https://doi.org/10.1080/026404104100016753 24

Anguera-Argilaga, M. T. (1999). Análisis de la competencia en la selección de observadores. Metodología de las ciencias del comportamiento, $1(1), 95-114$.

Bailey, R., \& Morley, D. (2006). Towards a model of talent development in physical education. Sport,
Education and Society, 11(3), 211-230. https://doi.org/10.1080/13573320600813366

Baker, J. (2003). Early Specialization in Youth Sport: A Requirement for Adult Expertise? High Ability Studies, 14(1), 85-94.

Baker, J., Côté, J., \& Abernethy, B. (2003). Learning from the Experts: Practice Activities of Expert Decision Makers in Sport. Research Quarterly for Exercise and Sport, 74(3), 342-347. https://doi.org/10.1080/02701367.2003.10609 101

Baker, J., Deakin, J., \& Cote, J. (2005). On the utility of deliberate practice: Predicting performance in ultra-endurance triathletes from training indices. International Journal of Sport Psychology, 36(3), 225-240.

Balyi, I. (2002). Long-term Athlete Development: the system and solutions Faster Higher Stronger. Faster Higher Stronger, (14), 9-12.

Bardin, L. (2011). Análise de conteúdo. Lisboa: Edições 70.

Carlson, R. (1988). The Socialization of Elite Tennis Players in Sweden: An Analysis of the Players' Backgrounds and Development. Sociology of Sport Journal, 5(3), 241-256. https://doi.org/10.1123/ssj.5.3.241

Côté, J., Baker, J., \& Abernethy, B. (2007). Practice and Play in the Development of Sport Expertise. Em G. Tenenbaum \& R. C. Eklund (Eds.), Handbook of Sport Psychology (3rd Ed., pp. 184-202). New York: John Wiley \& Sons.

Côté, J., Erickson, K., \& Abernethy, B. (2013). Practice and play in sport development. Em J. Côté \& R. Lidor (Eds.), Condition of children's talent development in sport (pp. 9-20). Morgantown: Fitness Information Technology.

Côté, J., \& Fraser-Thomas, J. (2007). Youth involvement in sport. Em P. Crocker (Ed.), Sport psychology: A Canadian perspective (pp. 270298). Toronto: Pearson.

Côté, J., Lidor, R., \& Hackfort, D. (2009). ISSP position stand: To sample or to specialize? Seven postulates about youth sport activities that lead to continued participation and elite performance. International Journal of Sport and Exercise Psychology, $7(1), \quad 7-17$. https://doi.org/10.1080/1612197X.2009.96718 89

Côté, J., Strachan, L., \& Fraser-Thomas, J. (2008). Participation, personal development, and performance through sport. Em N. L. Holt (Ed.), Positive youth development through sport (pp. 34-45). London: Routledge.

Davids, K., Araújo, D., Correia, V., \& Vilar, L. (2013). How small-sided and conditioned games enhance acquisition of movement and decision-making skills. Exercise and Sport Sciences Reviews, 41(3), 154-161. https://doi.org/10.1097/JES.0b013e318292f3ec

Ericsson, K. A., Krampe, R. T., \& Tesch-Romes, C. (1993). The Role of Deliberate Practice in the Acquisition of Expert Performance. Psychological 
Review, 100(3), 363-406. https://doi.org/10.1037//0033-295X.100.3.363

Ferreira, R. M., \& Moraes, L. C. de. (2012). Family influence in the first phase of the career development of Brazilian swimmers Olympic medalists. Motricidade, 8(2), 42-51. https://doi.org/10.6063/motricidade.8(2).711

Fradua, L., Zubillaga, A., Caro, Ó., Fernández-García, Á. I., Ruiz-Ruiz, C., \& Tenga, A. (2013). Designing small-sided games for training tactical aspects in soccer: Extrapolating pitch sizes from full-size professional matches. Journal of Sports Sciences, $\quad 31(6)$, 573-581. https://doi.org/10.1080/02640414.2012.74672 2

Fraser-Thomas, J., Côté, J., \& Deakin, J. (2005). Youth sport programs: an avenue to foster positive youth development. Physical Education and Sport Pedagogy, 10(1), 19-40. https://doi.org/10.1080/174089804200033489 0

Fraser-Thomas, J., Côté, J., \& Deakin, J. (2008). Understanding dropout and prolonged engagement in adolescent competitive sport. Psychology of Sport and Exercise, 9(5), 645-662. https://doi.org/10.1016/j.psychsport.2007.08.0 03

Fraser-Thomas, J., Côté, J., \& MacDonald, D. J. (2010). Community Size in Youth Sport Settings: Examining Developmental Assets and Sport Withdrawal. Revue phénEPS / PHEnex Journal, 2(2), 1-9.

Galatti, L. R. (2010). Esporte e Clube Sócio-esportivo: percurso, contextos e perspectivas a partir de estudo de caso em clube esportivo espanhol (Dissertação de Doutoramento em Educação Física). Universidade Estadual de Campinas, Campinas, SP.

Galatti, L. R., Reverdito, R. S., Scaglia, A. J., Paes, R. R., \& Seoane, A. M. (2014). Pedagogia do Esporte: tensão na ciência e o ensino dos Jogos Esportivos Coletivos. Journal of Physical Education, 25(1), 153-162. https://doi.org/10.4025/reveducfis.v25i1.21088

Heinemann, K. (1999). Sociología de las organizaciones voluntarias: el ejemplo del club deportivo. Valência: Tirant lo Blanch.

Henriksen, K., Stambulova, N., \& Roessler, K. K. (2010). Successful talent development in track and field: considering the role of environment. Scandinavian Journal of Medicine \& Science in Sports, 20(S2), 122-132. https://doi.org/10.1111/j.16000838.2010.01187.x

Henriksen, K., Stambulova, N., \& Roessler, K. K. (2011). Riding the Wave of an Expert: A Successful Talent Development Environment in Kayaking. The Sport Psychologist, 25(3), 341362. https://doi.org/10.1123/tsp.25.3.341

Hill-Haas, S. V., Dawson, B., Impellizzeri, F. M., \& Coutts, A. J. (2011). Physiology of small-sided games training in football: a systematic review.
Sports Medicine, 41(3), 199-220. https://doi.org/10.2165/11539740-00000000000000

Holt, N. L., \& Dunn, J. G. H. (2004). Toward a Grounded Theory of the Psychosocial Competencies and Environmental Conditions Associated with Soccer Success. Journal of Applied Sport Psychology, 16(3), 199-219. https://doi.org/10.1080/10413200490437949

Jakobsson, B. T. (2012). What makes teenagers continue? A salutogenic approach to understanding youth participation in Swedish club sports. Physical Education and Sport Pedagogy, 19(3), 239-252. https://doi.org/10.1080/17408989.2012.75400 3

Leite, N., Baker, J., \& Sampaio, J. (2009). Paths to Expertise in Portuguese National Team Athletes. Journal of Sports Science \& Medicine, 8(4), 560566.

MacDonald, D. J., Côté, J., Eys, M., \& Deakin, J. (2011). The Role of Enjoyment and Motivational Climate in Relation to the Personal Development of Team Sport Athletes. The Sport Psychologist, 25(1), 32-46. https://doi.org/10.1123/tsp.25.1.32

Morgan, T. K., \& Giacobbi, P. R. (2006). Toward Two Grounded Theories of the Talent Development and Social Support Process of Highly Successful Collegiate Athletes. The Sport Psychologist, 20(3), 295-313. https://doi.org/10.1123/tsp.20.3.295

Paes, R. R., \& Galatti, L. R. (2013). Pedagogia do Esporte: o esporte educacional no contexto do clube contemporâneo. Em C. E. B. Gonçalves (Ed.), Educação pelo Desporte e Associativismo Desportivo (pp. 85-110). Porto: Edições Afrontamento.

Phillips, E., Davids, K., Renshaw, I., \& Portus, M. (2010). Expert performance in sport and the dynamics of talent development. Sports Medicine (Auckland, N.Z.), 40(4), 271-283. https://doi.org/10.2165/11319430-00000000000000

Rodríguez Díaz, Á. (2008). El deporte en la construcción del espacio social. Madrid: Centro de Investigaciones Sociológicas (CIS).

Silva, R. M. P., Galatti, L. R., \& Paes, R. R. (2010). Pedagogia do esporte e iniciação esportiva tardia: perspectivas a partir da modalidade basquetebol. Pensar a Prática, 13(1), 1-15. https://doi.org/10.5216/rpp.v13i1.7629

Strachan, L., Côté, J., \& Deakin, J. (2011). A new view: exploring positive youth development in elite sport contexts. Qualitative Research in Sport, Exercise and Health, 3(1), 9-32. https://doi.org/10.1080/19398441.2010.54148 3

Vallée, C. N., \& Bloom, G. A. (2005). Building a Successful University Program: Key and Common Elements of Expert Coaches. Journal of 
Elite, participation and youth sport | $\mathbf{3 1}$

Applied Sport Psychology, 17(3), 179-196. https://doi.org/10.1080/10413200591010021

projeto social de educação não formal. Pensar a Prática, 14(3), $1-21$. Viola, G., Paes, R., Galatti, L., \& Ribeiro, S. (2011). Pedagogia do esporte e autonomia: um estudo em

(7) (9) All content of Journal Motricidade is licensed under Creative Commons, except when otherwise specified and in content retrieved from other bibliographic sources. 